Acta vet. scand. $1974,15,1-25$.

From the Department of Pathology, Veterinary College of Norway, Oslo.

\title{
OSTEOCHONDROSIS AND ARTHROSIS IN PIGS
}

\section{INCIDENCE IN ANIMALS UP TO 120 KG LIVE WEIGHT}

\author{
By \\ Trygve Grøndalen
}

GRØNDALEN, TRYGVE: Osteochondrosis and arthrosis in pigs. I. Incidence in animals up to $120 \mathrm{~kg}$ live weight. Acta vet. scand. 1974, $15,1-25$. - Joint and bone lesions in growing pigs are described on the basis of post-mortem examination of 341 gilts, boars or castrates from 10 to $120 \mathrm{~kg}$ live weight, and 869 separate bones from pigs between 80 and $115 \mathrm{~kg}$ live weight at slaughter. No evidence of rickets or generalized osteodystrophia fibrosa was found. Lesions occurred in both sexes. The typical osteochondral lesions were most often symmetrical, occurred at certain sites in joints and epiphyseal plates and were most obvious in the elbow and stifle joint, and in the distal epiphyseal plate of the ulna. Lesions of varying degree could be demonstrated in most pigs at $90-100 \mathrm{~kg}$ live weight. The use of the diagnosis osteochondrosis is suggested for local primary non-inflammatory disturbances which lead to a failure of endochondral ossification in joint cartilage as well as in epiphyseal plates. The diagnosis arthrosis is used when the superficial layer of the joint cartilage is affected. Investigations of the early changes in the medial condyle of the femur suggest that the osteochondral lesions start in the deep layers of the joint cartilage. Arthrosis occurred frequently in the lumbar intervertebral joints of Norwegian pigs. Otherwise the lesions appeared to be identical with those described from other countries.

osteochondrosis; arthrosis; pig.

This article is the first one in a series in which an attempt is made to throw light on the incidence and causes of locomotory problems in the pig*.

The incidence of joint and bone lesions in pigs. has been investigated in a number of countries during the last 20 years. From Sweden Christensen (1953) described the ocurrence of pronounced changes in the larger joints of both fore and hind

- The work was supported by grants from the Agricultural Research Council of Norway. 
legs of Landrace boars at 9 months and more of age. The most constant lesion was a deformity of the head of the femur with a more or less pronounced crest against the neck and degeneration of the cartilage. No evidence of rickets was found. Bacteriological examinations of the joint capsules were negative. Christensen used the term chronic deforming arthrosis and concluded that the lesions were an excellent explanation for the clinical symptoms. Sabec et al. (1961) in German investigations described deforming arthrosis in the medial aspect of the tarsal joints in over $80 \%$ of imported Dutch Landrace pigs. The proximal joints and bones were not investigated. From England Thurley (1965) described 3 types of joint cartilage changes: 1) Wear lesions with thin cartilage and no reaction of the subchondral bone tissue in the early stages, most often demonstrated on the head of the femur and the head of the humerus, 2) Proliferative lesions with collapse of the subchondral bone tissue and formation of so-called "brood capsules" in the cartilage, most of ten demonstrated in the condyles and the head of femur, and 3 ) Lift lesions in which the cartilage was detached from the subchondral bone tissue, most often found in the semilunar notch of the elbow joint. Walker et al. (1966), also from England, described a special lesion of the distal epiphyseal plate of the ulna with patho-anatomically 3 main types of lesions: 1) The lesion in cartilage, 2 ) The lesion in the zone of provisional calcification, 3) The process of repair. Lauprecht et al. (1967) in German investigations demonstrated, radiologically, deforming arthrosis in the elbow joint of $13.3 \%$, in the stifle joint of $33.3 \%$ and in the hock joint in $80 \%$ of animals from 6 to 12 months of age. At 4 years of age, the incidence was $10 \%, 70 \%$, and $80 \%$, respectively. In Sweden, Hansen \& Reiland (1968) came to the conclusion that locomotory problems in the pigs are mainly connected with joint conditions and that arthrosis deformans dominated completely. Joint lesions occurred systematically and symmetrically and could also be demonstrated in the intervertebral joints. Thurley (1969) carried out histological examinations of epiphyseal cartilage from 36 clinically normal pigs and 13 pigs with leg weakness. The animals were between 47 and 160 days old and of varying breed and sex. He frequently demonstrated the occurrence of the following deviations from the normal: 1 : Eosinophilic streaking, 2) Eosinophilic patches, 3 ) Local irregularity of the length of columns of cartilage cells, 4) Endo- 
chondral osseous dysplasia, 5) Aberrations in the direction of the columns of cartilage cells. Eosinophilic streaking and patches consisted of amorphous, eosinophilic PAS-positive material in the epiphyseal plate. Thurley used the term endochondral osseous dysplasia when describing the lesions in the distal epiphyseal plate of the ulna, among others reported by Walkër et al. Ljunggren \& Reiland (1970) demonstrated degenerative joint lesions, mainly localized to the large diarthrodial joints, in $80 \%$ of a material comprising 250 pigs. Infoldings and erosions in the joint cartilage were noted symmetrically and at certain locations. Lesions in the growth plate were also seen. Histological examination of early cases revealed degenerative processes in the basal zone of the thickened joint cartilage. In the more advanced stages, fissures and clefts occurred in the cartilage. The condition led to disturbed endochondral ossification. They suggested applying the diagnosis osteochondrosis to these lesions. $J u b b \&$ Kennedy (1970) apply the diagnosis osteochondritis to flaking defects of juvenile articular cartilage. In Germany, Bollwahn et al. (1970) demonstrated hydrops of the talocrural joint in approx. 1 month old pigs. These later developed deforming arthrosis of the tarsus. The animals were examined up to 8 months of age. The joint changes were mainly confined to the tarsus. Radiological examination revealed deforming arthrosis in about $40 \%$ of 6 months old pigs and in about $80 \%$ of 8 months old pigs. Vaughan (1971) tabulated, on the basis of a study of the literature as well as on his own observations, 3 main groups of pathological findings in the skeleton of pigs: 1) Distal ulnar lesions, 2) Articular cartilage defects as described by Thurley (1965), and 3) Epiphyseolysis capitis femoris.

From Denmark, Nielsen (1973) described arthrotic changes which he grouped in 3 main types: 1) Invagination of articular cartilage with fibrous replacement of subchondral bone, 2) Local splitting and fibrillation of articular cartilage with erosions and exposed, of ten excavated, subchondral bone, 3 ) Deformations of joint surfaces and abnormal position of epiphyses.

In Norway, Nordrum (1968) described polyarthrotical changes of non-ricket nature and epiphyseal separation in the pig. After observing pigs taking part in feeding trials he came to the conclusion that such disease conditions were probably quite common in Norwegian slaughter pigs. Garm (1968) demonstrated a high incidence of cartilage changes in joints of the extremities from 
boars with leg weakness, and was of the opinion that leg weakness in young boars was a significant problem in Norway.

In order to clarify the occurrence of joint and bone lesions in growing Norwegian pigs, different materials were collected and examined during the period 1969-1971. As several authors have discussed seemingly identical lesions and have come to the same conclusions, a complete review of the comprehensive literature concerning the problem complex of leg weakness and arthrosis will not be made.

\section{MATERIALS AND METHODS}

The materials consisted of skeletons from 341 pigs from 10 to $120 \mathrm{~kg}$ live weight, and 869 separate bones from pigs from 80 to $115 \mathrm{~kg}$ live weight. A general survey of the materials is shown in Tables 1 and 2.

The pigs in material I came from the Boar Testing Station, Bjørke, of the Norwegian Pig Breeders Association. The material consisted of the boars that were slaughtered (40 to $50 \%$ ). The most common reasons for slaughter were low testing index and leg weakness. The material was therefore selected. Material II

Table 1. Materials including the whole skeleton or larger parts of it.

\begin{tabular}{|c|c|c|c|c|c|c|c|c|c|c|}
\hline \multirow[b]{3}{*}{ Material } & \multirow[b]{3}{*}{$\begin{array}{l}\text { Num- } \\
\text { ber } \\
\text { of } \\
\text { pigs }\end{array}$} & \multirow[b]{3}{*}{ Sex } & \multirow[b]{3}{*}{$\begin{array}{l}\text { Raising } \\
\text { conditions }\end{array}$} & \multirow{3}{*}{\multicolumn{2}{|c|}{$\begin{array}{l}\text { Live } \\
\text { weight } \\
\text { when } \\
\text { killed }\end{array}$}} & \multicolumn{5}{|c|}{ Number of pigs } \\
\hline & & & & & & \multicolumn{3}{|c|}{ grossly investigated } & \multicolumn{2}{|c|}{$\begin{array}{l}\text { histologically } \\
\text { investigated }\end{array}$} \\
\hline & & & & & & $\begin{array}{c}\text { Pore } \\
\text { and } \\
\text { hind } \\
\text { limbs }\end{array}$ & $\begin{array}{c}\text { lumbar } \\
\text { inter- } \\
\text { verte- } \\
\text { bral } \\
\text { joints }\end{array}$ & $\begin{array}{c}\text { lumbar } \\
\text { inter- } \\
\text { verte- } \\
\text { bral } \\
\text { discs }\end{array}$ & $\begin{array}{c}\text { costo- } \\
\text { chondral } \\
\text { junction } \\
\text { of ribs }\end{array}$ & $\begin{array}{c}\text { lesions } \\
\text { in joints } \\
\text { and epi- } \\
\text { physeal } \\
\text { plates }\end{array}$ \\
\hline I & 106 & boars & $\begin{array}{l}\text { performance } \\
\text { testing } \\
\text { station }\end{array}$ & $100-120$ & kg & 106 & 12 & 56 & 106 & 60 \\
\hline II & 100 & $\begin{array}{l}\text { females } \\
\text { and cas- } \\
\text { trates }\end{array}$ & $\begin{array}{l}\text { research } \\
\text { station }\end{array}$ & about 100 & ” & 100 & 100 & 100 & 50 & 40 \\
\hline III & 74 & ” & $\begin{array}{l}\text { performance } \\
\text { testing } \\
\text { station }\end{array}$ & " $\quad 90$ & " & 74 & none & none & 20 & none \\
\hline IV & 61 & $\begin{array}{l}\text { females, } \\
\text { males and } \\
\text { castrates }\end{array}$ & various & $10-80$ & ” & 61 & none & none & 30 & 61 \\
\hline
\end{tabular}


T a b le 2. Materials including separate bones from 2 different meat processing establishments.

\begin{tabular}{|c|c|c|c|c|}
\hline Material & $\begin{array}{l}\text { Type of } \\
\text { sample }\end{array}$ & $\begin{array}{l}\text { Live weight } \\
\text { of the pig }\end{array}$ & $\begin{array}{c}\text { Number } \\
\text { of bones } \\
\text { grossly } \\
\text { investigated }\end{array}$ & $\begin{array}{c}\text { Number } \\
\text { of lesions } \\
\text { histologically } \\
\text { investigated }\end{array}$ \\
\hline V & humerus & $80-115 \mathrm{~kg}$ & 465 & 10 \\
\hline VI & femur & $105-115$ & 306 & 10 \\
\hline VII & radius/ulna & $80-115$ & 98 & 5 \\
\hline
\end{tabular}

comprised pigs from the Veterinary College of Norway's research station, Arteid. The herd was based on artificial insemination using semen from boars standing at Norwegian boar stations. Material III was from one of the pig performance testing stations of the Norwegian Pig Breeders Association, and comprised pigs used in litter mate or offspring trials for the selection of breeding animals. In all 3 oases, the ration fed contained $0.6-1.0 \% \mathrm{Ca}$ and $0.5-0.8 \% \mathrm{P}$ with a $\mathrm{Ca}: \mathrm{P}$ ratio near $1.2: 1.0$. The pigs in material I received the largest amount of minerals, while the pigs in material III up to $60 \mathrm{~kg}$ live weight received the least. Commercial pig rations were fed. Feeding levels were average for Norwegian conditions. The animals were stunned by electric shock and slaughtered in the usual manner. The meat was trimmed off and the skeleton labelled for later investigation. The animals comprising material IV came from different farms and were collected at the Department of Pathology, Veterinary College of Norway. They had died from enteritis, acute heart failure, muscle degeneration, gastric ulcers, or pneumonia. In addition, material IV comprised 18 pigs from an investigation involving intravenous injections of E. coli endotoxin. Materials I-IV comprised Norwegian Landrace pigs. Materials V, VI and VII were collected in connection with boning out of pigs at 2 different meat processing establishments, 1 in the east (Oslo) and 1 in the west of Norway (Rogaland).

The investigation included examination for ruptures and haemorrhages in the joint ligaments and capsules, examination for anthritis, osteochondrosis and arthrosis in the joints of the extremities and intervertebral joints of the lumbar region, and investigation for patho-anatomical conditions in the epiphyseal plates, in the sacroiliac joints and in the intervertebral dises in the lumbar region. When necessary, the cartilage and bone tissue 
was sectioned with a saw or knife in order to disclose hidden lesions. As shown in Tables 1 and 2, sections for histological examination were taken from joint cartilage and the subchondral bone tissue, and epiphyseal plates showing lesions. Sections were also taken from the costochondral junction of the ribs for investigation as to rickets. The medial condyle of the femur was examined histologically in all, and the medial condyle of the humerus in 30 of the pigs comprising material IV. Sections were taken at right angles to the cartilage in the longitudinal direction of the bones. They were fixed in $10 \%$ formalin, and decalcified by the formic acid/sodium citrate method (Manual of Histologic and Special Staining Techniques. Armed Forces Institute of Pathology, 2nd Ed., Mc Graw-Hill Book Company, 1960, pp. 38-39). They were thereafter treated routinely and stained using the haematoxylin-eosin (H.E.), and van Gieson (v. G.) methods. Bacteriological examinations were carried out on 10 joint capsules and 5 intervertebral discs, all patho-anatomically changed ${ }^{\star}$.

Both the right and left extremities in materials I, II, and IV were examined. Otherwise it can be seen from the tables that only materials I and II were examined fully.

The use of the diagnosis osteochondrosis in addition to arthrosis might seem confusing. The diagnosis osteochondrosis is used about local degenerative lesions in epiphyseal plates and the deep layer of joint cartilage. Arthrosis is used when primarily degenerative or proliferative lesions affect the superficial, or the superficial and the deep layers of the joint cartilage.

\section{RESULTS}

\section{Gross examination}

Changes in joint cartilage and associated bone tissue

The main changes can be grouped as follows:

1) Thin reddish cartilage, the surface of which was below the level of the surface of the surrounding joint cartilage. There were no demonstrable changes in the subchondral bone tissue. This change was seen most often on the head of the humerus towards the bicipital groove, covering an area of $1 / 2$ to $3 \mathrm{~cm}^{2}$, and on the head of the femur towards the trochanter, here most often covering a lesser area than in the case of the head of the humerus.

* The bacteriological examinations were carried out at the Department of Microbiology and Immunology, Veterinary College of Norway. 


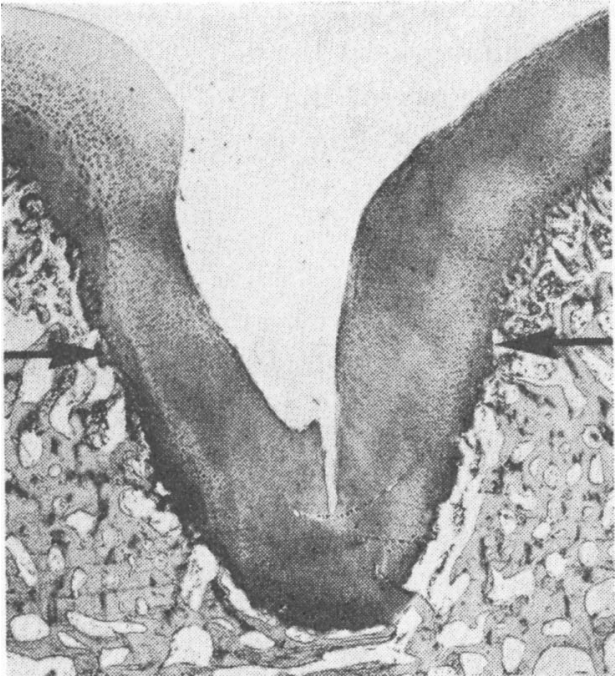

Fig u r e 1. Section from the scapula of a $100 \mathrm{~kg}$ pig with invaginated cartilage (arrows) of the joint surface into the subchondral bone tissue. (H. E.) $\times$ 15. Diagnosis: Osteochondrosis.

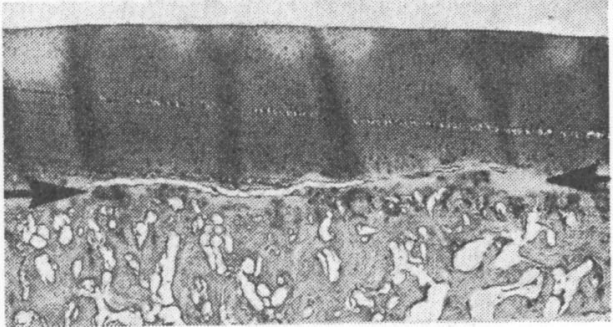

Figure 2. Section from the medial condyle of the femur of a $100 \mathrm{~kg}$ pig with a cleft (arrows), partly filled with fibrous tissue, along the osteochondral junction. (H.E.) $\times 15$. Diagnosis: Osteochondrosis. (Artifacts in the cartilage).

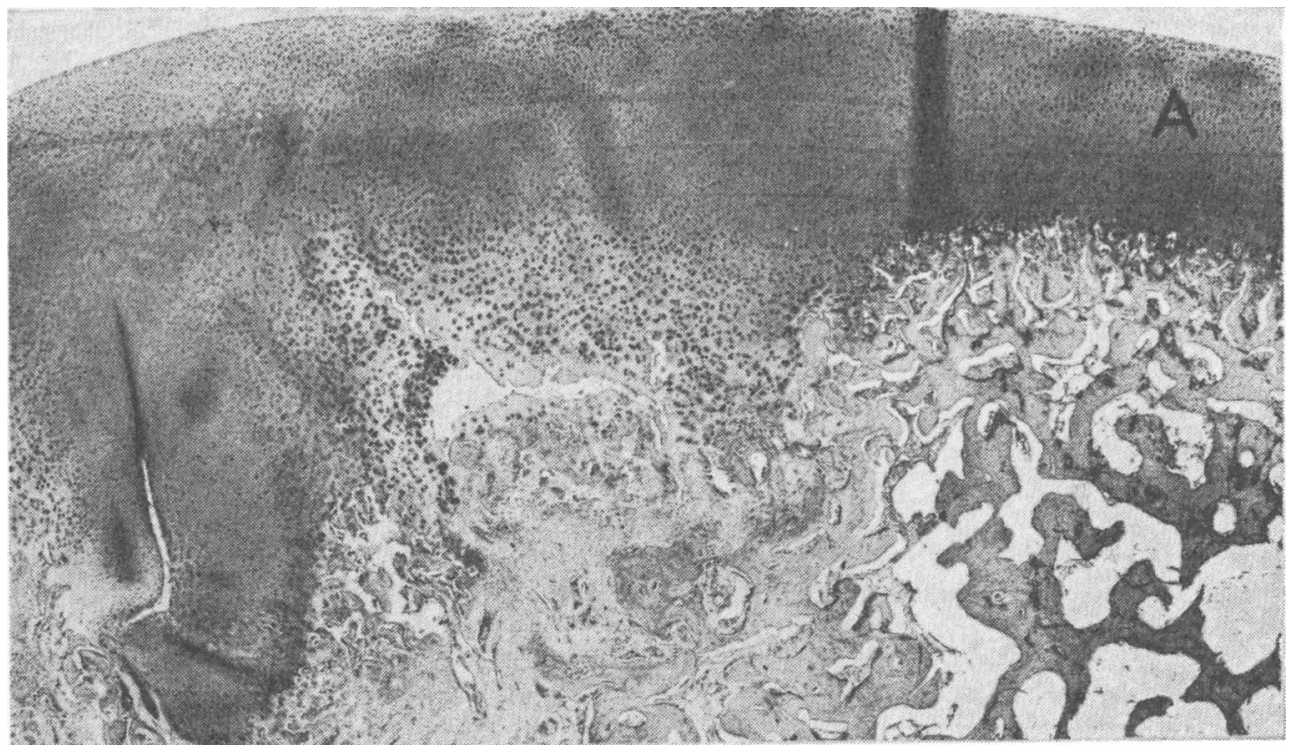

Figure 3. Section from the medial condyle of the humerus of a $100 \mathrm{~kg}$ pig with invaginated, thickened joint cartilage, brood capsules and partly fibrous replacement of the subchondral bone tissue. A: normal joint cartilage. (H.E.) $X$ 15. Diagnosis: Osteochondrosis. 
2) Invagination, and sometimes thickening of the cartilage, usually without gross demonstrable changes in the bone tissue. The most common location was at the centre of the joint surface on the scapula. This was the case for $85 \%$ of the pigs comprising material II. The invagination was about $1 / 2 \mathrm{~cm}$ in diameter and about $1 / 2 \mathrm{~cm}$ deep (Fig. 1).

3 ) Separation of the outermost layer of cartilage with fissuring in the cartilage parallel with the surface. This was uncommon, but when found, covering an area from $1 / 2$ to $2 \mathrm{~cm}^{2}$ at the medial condyle of the femur or humerus.

4) Separation of normal thick cartilage along the osteochondral junction. If fracture of the cartilage had taken place, pieces of cartilage had sometimes fallen out leaving the underlying bone tissue exposed. The lesion was found covering an area of from $1 / 2$ to $3 \mathrm{~cm}^{2}$, affecting the medial condyle of the humerus, the semilunar notch, the medial condyle of the femur (Fig. 2), the joint surface on the scapula, and the intervertebral joints.

5) Thickened cartilage with a normal or slightly uneven surface, often associated with haemorrhages and connective tissue formation in the subchondral bone tissue. This was very common in the medial condyle of the femur, being from small pinpoints to about $3 \mathrm{~cm}^{2}$ in extent (Figs. 14 and 15). Similar changes were found affecting the lateral condyle of the femur, the distal part of the talus, the condyles of the humerus (Fig. 3), and the joint surface of the scapula.

6) Split, separated or folded cartilage with subchondral collapsed, often exposed bone tissue, haemorrhages, connective tissue formation and necroses. 'This seemed to be a further development of the lesion described under 5), especially with regard to the medial condyle of the femur. The lesion was up to $4 \mathrm{~cm}^{2}$ in area, and was most often found affecting the medial condyle of the humerus (Fig. 4), the medial condyle of the femur (Figs. 5 and 6), the semilunar notch (Fig. 7), and as small defects effecting the mediodistal aspect of the talus. Joint mice occurred.

7) Chip fractures of the bone tissue. This lesion was found affecting the dorsal aspects of the cranial articular processes of the sacrum (Fig. 8), the tip of the caudal articular processes in the lumbar region, the semilunar notch of the ulna, the medial condyle of the humerus (Fig. 9), and the joint surface of the scapula.

8) Osteophyte formation along the joint edge. This was most 


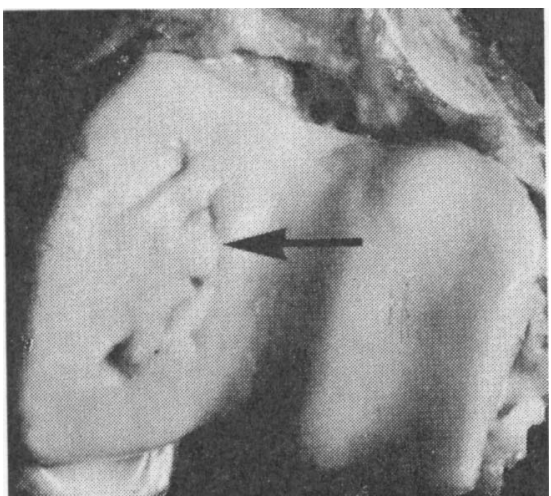

F i g u re 4. Split, invaginated cartilage with collapsed subchondral bone tissue (arrow) in the medial condyle of the humerus of a $100 \mathrm{~kg}$ pig. Diagnosis: Arthrosis.

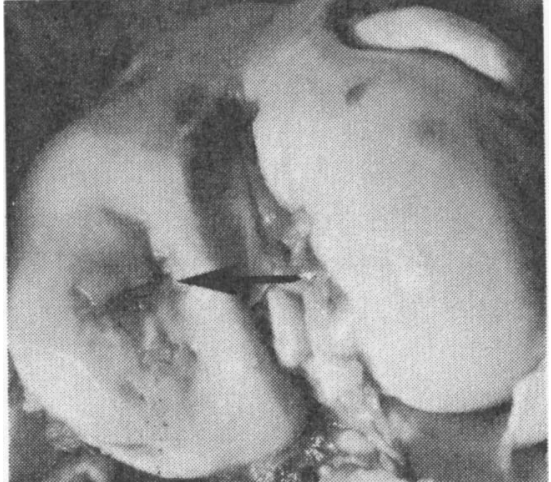

F i g u re 5. Split, separated and invaginated cartilage with collapsed and exposed subchondral bone tissue (arrow) in the medial condyle of the femur of a $100 \mathrm{~kg}$ pig. Diagnosis: Arthrosis.

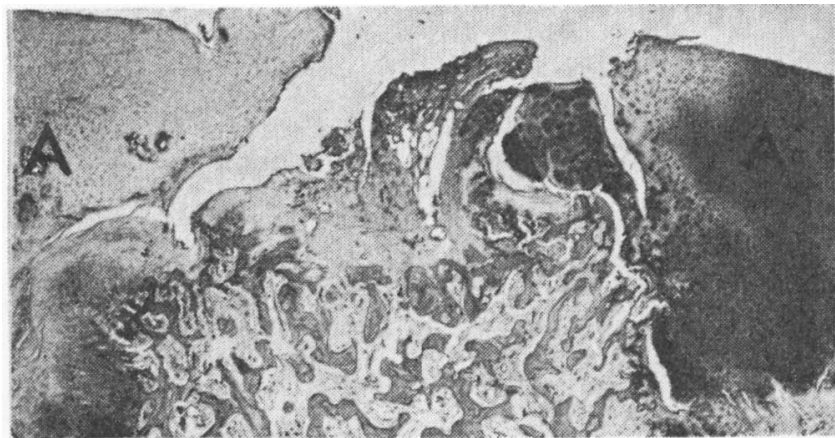

Figure 6. Section from the medial condyle of the femur of a $100 \mathrm{~kg}$ pig with split, separated, thickened joint cartilage, exposed and collapsed subchondral bone tissue and fibrous tissue formation. A: joint cartilage. (H.E.) $\times 15$. Diagnosis: Arthrosis.

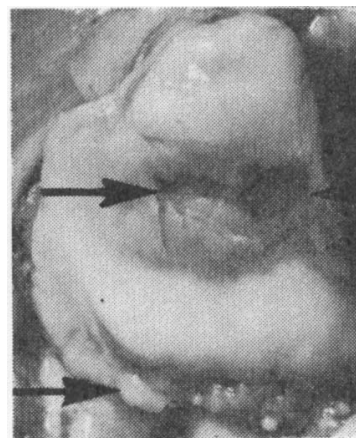

F i gu re 7. Split, separated cartilage with collapsed, exposed subchondral bone tissue (arrow) and osteophyte formation along the joint edge (arrow) in the semilunar notch of a $100 \mathrm{~kg}$ pig. Diagnosis: Arthrosis. 
often demonstrated in the intervertebral joints of the lumbar region, usually together with deformation of the joint surface (Fig. 10). Osteophyte formation was also relatively common along the edge of the elbow joint (Fig. 7)'. Apart from 2 animals in material $I$, this was always observed together with cartilage changes in the same joint. Dull eroded joint cartilage and osteophyte formation along the joint edge were also present at the distal medial aspect of the hock joint in some of the oldest animals.

\section{Changes in the epiphyseal plates}

The main changes can be grouped as follows:

1) Uneven, locally thickened cartilage with haemorrhages, homogeneous masses, islets of cartilage, and fibrous tissue in the metaphysis. These lesions were very often found in the distal epiphyseal plate of the ulna (Fig. 11), seldom in other epiphyseal plates or metaphyses. The degree varied from small local irregularities to changes affecting the whole area of the plate and the metaphysis with movement at the site so that an epiphyseal separation was present. Local periostitis occurred in the area of the metaphysis.

2) Distinct bony cone-shaped projections with their base in the epiphysis. They went through the epiphyseal plate and into the metaphysis, were up to $3 \mathrm{~cm}$ long, had pointed ends, and a basal area up to $1 \mathrm{~cm}^{2}$. These were most often found at the distal epiphyseal plate of femur (Figs. 12 and 13). Occasionally 3 large projections were present in this plate at the same time. In those cases where there was just 1 , it was most often positioned laterally where the epiphyseal plate was distinctly folded. The second was at the corresponding site medially, and the third was at the medioplantar aspect where the epiphyseal plate was usually relatively flat. Independent of other lesions empty cavities, usually about $1 \mathrm{~cm}$ in diameter, were found near up to the epiphyseal plate in the distal femoral epiphysis.

3) Thick rounded bony projections with their base in the epiphysis. They went through the epiphyseal plate and into the metaphysis, were up to $1 \mathrm{~cm}$ long, rounded and sometimes necrotic at the top and up to $1 \mathrm{~cm}^{2}$ at the base. They were usually located in the epiphyseal plates of the head of the femur and humerus, in the area towards the trochanter of the femur and towards the bicipital groove of the humerus. 


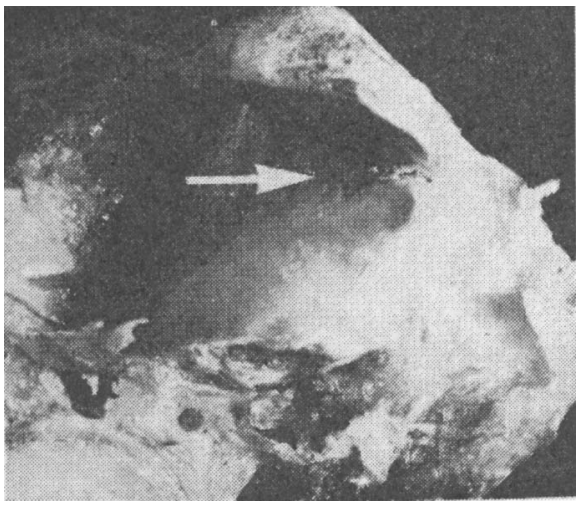

Figure 8. Chip fracture (arrow) of the articular process of the first sacral vertebrae of a 100 kg pig.

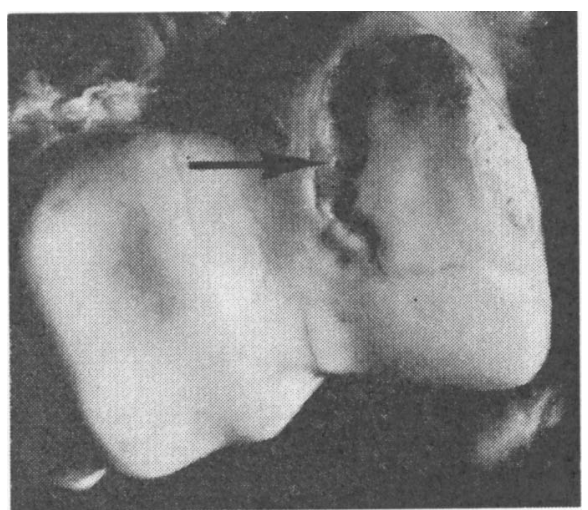

Figure 9. Chip fracture (arrow) of the medial condyle of the humerus of a $115 \mathrm{~kg}$ pig.

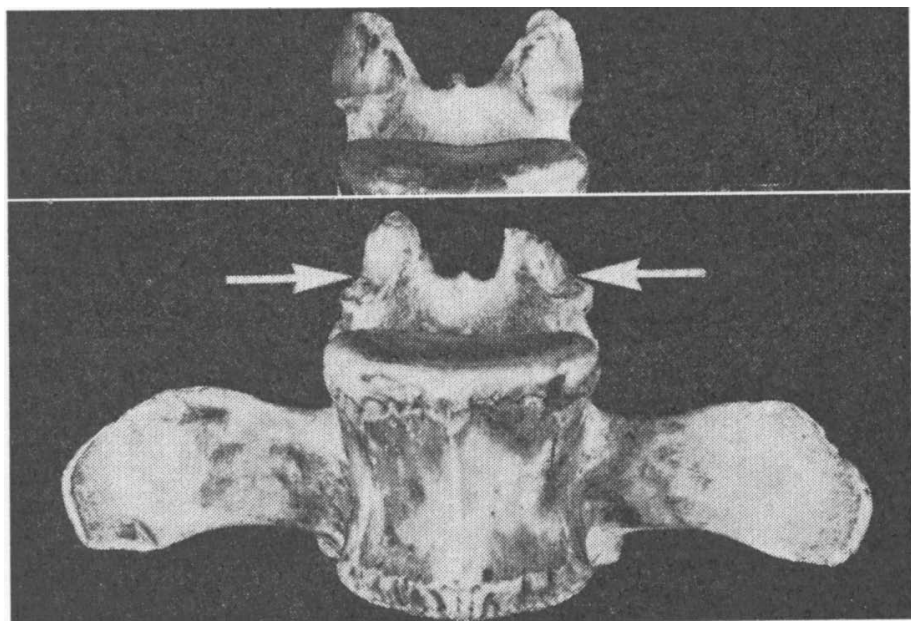

Figure 10 . Osteophyte formation and joint surface deformation (arrows) in a lumbar intervertebral joint of a $115 \mathrm{~kg}$ pig. Diagnosis: Arthrosis. The upper part of the figure shows normal articular processes. 
4) Premature closure of epiphyseal plates. This occurred at the head of the femur, starting at the same site as mentioned in 3 ). 5) Epiphyseal separation. Complete separation occurred most often at the head of the femur and at tuber ischii, and partial separation seemed to occur most commonly in the distal epiphyseal plate of the ulna.

\section{Changes in the intervertebral discs}

The nucleus pulposus could be haemorrhagic, granular, yellowish, firm and almost absent, or changed to a homogeneous, often darkly coloured, mass which could also project into the vertebral bodies. The annulus fibrosus could. be yellow in colour centrally or dark and obviously degenerated. Disc prolapse into the spinal canal was not demonstrated. Anchylosing spondylosis occurred.

\section{Other recorded changes}

Small villous proliferations together with oedema were often present in the synovial layer of the joint capsules, sometimes also haemorrhages in the capsule. Haemorrhages, for the most part fresh, also occurred in the joint ligaments, being especially frequent in the teres ligament of the hip joint. This had separated from the acetabulum in 1 of the pigs in material I. Haemorrhages in the sacroiliac joint were occasionally demonstrated in materials I and II. Lesions in the distal joints of the extremities were relatively uncommon.

The incidence of gross lesions in various joints of the extremities, epiphyseal plates, and the lumbar section of the spinal column

The incidence of the most frequently occurring gross lesions in the skeleton of the examined pigs is given in Tables $3-7$. Which types of change were most frequent in the various joints and epiphyseal plates is discussed under the previous description of the changes. The lesions were most often symmetrical. This was the case for $89 \%$ of the findings in the elbow joint in material II. The most marked lesions occurred most commonly in the medial condyle of the femur (Fig. 5) and humerus (Fig. 4), in the distal epiphyseal plate of the ulna (Fig. 11) and in the lumbar intervertebral joints (Fig. 10). 


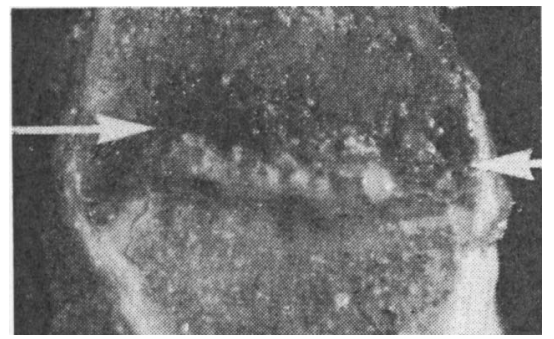

Figure 11. Section from the distal part of the ulna of a $100 \mathrm{~kg}$ pig with locally thickened epiphyseal plate, haemorrhages, homogeneous masses and bone tissue colkapse in the metaphysis. Diagnosis: Osteochondrosis.
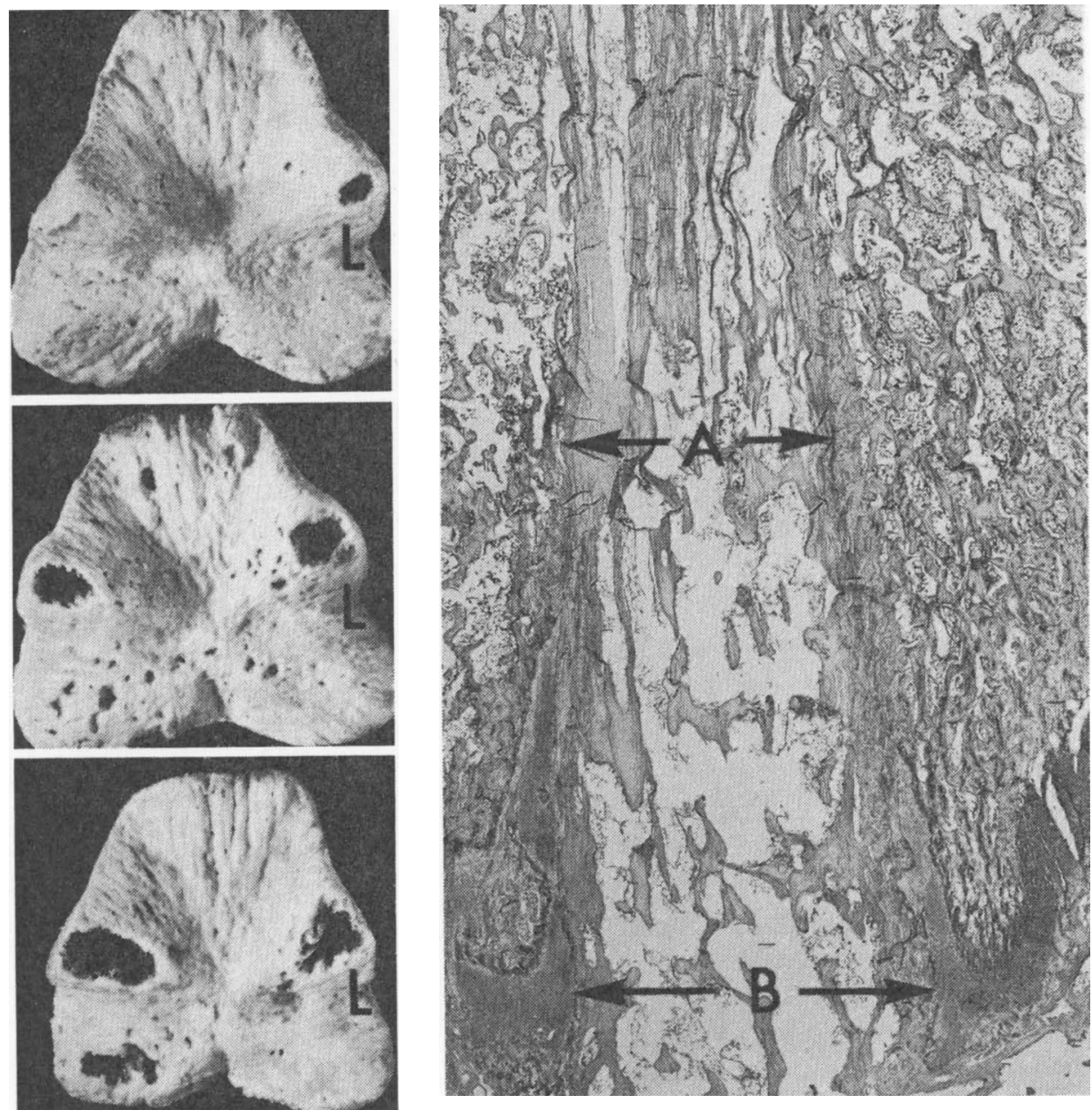

F i g u r e 12. Cavities after coneshaped projections in the distal metaphysis of the femur of $100 \mathrm{~kg}$ pigs. The epiphysis and the metaphysis are artificially separated along the epiphyseal plate.

L: lateral.

F igu re 13. Section of cone-shaped projection from the epiphysis penetrating the metaphysis of the femur of a $100 \mathrm{~kg}$ pig. Arrows A: Fibrous tissue along the side of the projection. Arrows B: Epiphyseal plate. (H.E.) $\times 10$. 
T a b l e 3. Results from gross examination of the elbow joint.

\begin{tabular}{|c|c|c|c|c|c|c|c|c|c|c|c|c|}
\hline \multirow[b]{3}{*}{ Diagnosis } & \multicolumn{12}{|c|}{ Material } \\
\hline & \multicolumn{2}{|c|}{ I (106 pigs) } & \multicolumn{2}{|c|}{ II (100 pigs) } & \multicolumn{2}{|c|}{ III (74 pigs) } & \multicolumn{2}{|c|}{ IV (61 pigs) } & \multicolumn{2}{|c|}{ V (465 humeri) } & \multicolumn{2}{|c|}{$\begin{array}{c}\text { VII (98 } \\
\text { radil/ulnae) }\end{array}$} \\
\hline & $\begin{array}{c}\text { num- } \\
\text { ber }\end{array}$ & $\%$ & $\begin{array}{c}\text { num- } \\
\text { ber }\end{array}$ & $\%$ & $\begin{array}{c}\text { num- } \\
\text { ber }\end{array}$ & $\%$ & $\begin{array}{c}\text { num- } \\
\text { ber }\end{array}$ & $\%$ & $\begin{array}{c}\text { num- } \\
\text { ber }\end{array}$ & $\%$ & $\begin{array}{c}\text { num- } \\
\text { ber }\end{array}$ & $\%$ \\
\hline normal joint & 46 & 43.4 & 46 & 46.0 & 51 & 68.9 & 60 & 98.4 & 317 & 68.2 & 81 & 82.7 \\
\hline $\begin{array}{l}\text { osteochondrosis } \\
\text { and arthrosis in } \\
\text { the medial con- } \\
\text { dyle of humerus }\end{array}$ & 46 & 43.4 & & & & & & & 128 & 27.5 & & \\
\hline $\begin{array}{l}\text { osteochondrosis } \\
\text { and arthrosis in } \\
\text { the lateral con- } \\
\text { dyle of humerus }\end{array}$ & 5 & 4.7 & 42 & 42.0 & 21 & 28.4 & 1 & 1.6 & 15 & 3.2 & & \\
\hline $\begin{array}{l}\text { osteochondrosis } \\
\text { and arthrosis in } \\
\text { the semilunar } \\
\text { notch }\end{array}$ & 21 & 19.8 & 18 & 18.0 & 8 & 10.8 & 0 & 0.0 & & & 17 & 17.3 \\
\hline $\begin{array}{l}\text { osteophyte } \\
\text { formation }\end{array}$ & 15 & 14.2 & 23 & 23.0 & 7 & 9.5 & 0 & 0.0 & 18 & 3.9 & 12 & 12.2 \\
\hline
\end{tabular}

T a b l e 4. Results from gross examination of the medial condyle of the femur.

\begin{tabular}{|c|c|c|c|c|c|c|c|c|c|c|}
\hline \multirow[b]{3}{*}{ Diagnosis } & \multicolumn{10}{|c|}{ Material } \\
\hline & \multicolumn{2}{|c|}{ I (106 pigs) } & \multicolumn{2}{|c|}{ II (100 pigs) } & \multicolumn{2}{|c|}{ III (74 pigs) } & \multicolumn{2}{|c|}{ IV (61 pigs) } & \multicolumn{2}{|c|}{ VI (306 femurs } \\
\hline & $\begin{array}{c}\text { num- } \\
\text { ber }\end{array}$ & $\%$ & $\begin{array}{c}\text { num- } \\
\text { ber }\end{array}$ & $\%$ & $\begin{array}{l}\text { num- } \\
\text { ber }\end{array}$ & $\%$ & $\begin{array}{c}\overline{\text { num- }} \\
\text { ber }\end{array}$ & $\overline{\%}$ & $\begin{array}{l}\text { num- } \\
\text { ber }\end{array}$ & $\%$ \\
\hline normal condyle & 5 & 4.7 & 14 & 14.0 & 17 & 23.0 & 41 & 67.2 & 90 & 29.4 \\
\hline asteochondrosis & 89 & 84.0 & 70 & 70.0 & 53 & 71.6 & 20 & 32.8 & 200 & 65.4 \\
\hline arthrosis & 12 & 11.3 & 16 & 16.0 & 4 & 5.4 & 0 & 0 & 16 & 5.2 \\
\hline
\end{tabular}


Table 5. Results from gross examination of the lumbar part of the vertebral column.

\begin{tabular}{|c|c|c|c|c|}
\hline \multirow[b]{2}{*}{ Diagnosis } & \multicolumn{2}{|c|}{$\begin{array}{l}\text { Material I } \\
\text { (106 pigs) }\end{array}$} & \multicolumn{2}{|c|}{$\begin{array}{l}\text { Material II } \\
\text { (100 pigs) }\end{array}$} \\
\hline & number & $\%$ & number & $\%$ \\
\hline normal lumbar intervertebral joints & 6 & $50.0^{*}$ & 65 & 65.0 \\
\hline $\begin{array}{l}\text { arthrosis, chip fractures, joint } \\
\text { mice and osteochondrosis in the } \\
\text { intervertebral joints }\end{array}$ & 6 & $50.0^{*}$ & 35 & 35.0 \\
\hline $\begin{array}{l}\text { normal lumbar corpora and inter- } \\
\text { vertebral discs }\end{array}$ & 48 & $85.7^{* *}$ & 85 & 85.0 \\
\hline $\begin{array}{l}\text { pathological changes in the } \\
\text { intervertebral discs }\end{array}$ & 7 & $12.5^{\star \star}$ & 15 & 15.0 \\
\hline vertebral anchylosing spondylosis & 1 & $1.8^{* *}$ & 1 & 1.0 \\
\hline
\end{tabular}

* 12 pigs investigated.

* 56 pigs investigated.

T a b l e 6. Results from gross examination of the tarsal joints.

\begin{tabular}{|c|c|c|c|c|c|c|}
\hline \multirow[b]{3}{*}{ Diagnosis } & \multicolumn{6}{|c|}{ Material } \\
\hline & \multicolumn{2}{|c|}{ I (106 pigs) } & \multicolumn{2}{|c|}{ II (100 pigs) } & \multicolumn{2}{|c|}{ III (74 pigs) } \\
\hline & number & $\%$ & number & $\%$ & number & $\%$ \\
\hline $\begin{array}{l}\text { osteochondrosis and arthro- } \\
\text { sis distal in the talus }\end{array}$ & 55 & $70.5^{*}$ & 65 & 65.0 & 43 & 58.1 \\
\hline $\begin{array}{l}\text { arthrosis in the distal } \\
\text { tarsal joints }\end{array}$ & 10 & $21.3 * *$ & n.i. * * & & n.i. & \\
\hline
\end{tabular}

* 78 pigs investigated.

* 47 pigs investigated.

** n.i.: not investigated. 
T a ble 7. Results from gross examination of epiphyseal plates.

\begin{tabular}{|c|c|c|c|c|c|c|c|c|c|c|}
\hline \multirow[b]{3}{*}{ Diagnosis } & \multicolumn{10}{|c|}{ Material } \\
\hline & \multicolumn{2}{|c|}{ I (106 pigs) } & \multicolumn{2}{|c|}{ II (100 pigs) } & \multicolumn{2}{|c|}{ IV (61 pigs) } & \multicolumn{2}{|c|}{ VI (306 femurs) } & \multicolumn{2}{|c|}{ VII (98 ulnae } \\
\hline & $\begin{array}{c}\text { num- } \\
\text { ber }\end{array}$ & $\%$ & $\begin{array}{c}\text { num- } \\
\text { ber }\end{array}$ & $\%$ & $\begin{array}{c}\text { num- } \\
\text { ber }\end{array}$ & $\%$ & $\begin{array}{l}\text { num- } \\
\text { ber }\end{array}$ & $\%$ & $\underset{\text { ber }}{\text { num- }}$ & $\%$ \\
\hline
\end{tabular}

osteochondrasis in the distal epiphyseal plate and the metaphysis of ulna $\begin{array}{llllll}77 & 72.6 & 61 & 61.0 & 5 & 8.2\end{array}$ $65 \quad 66.3$

projections in the distal epiphyseal plate and the metaphysis of femur

$\begin{array}{llllll}\text { n.i. } & 36 & 36.0 & \text { n.i. } & 64 & 20.9\end{array}$

projections in the epiphyseal plate and the metaphysis of the caput femoris

n.i.

n.i.

n.i. $205 \quad 67.0$

epiphyseolysis of caput femoris (unilateral)$$
2 \quad 1.9
$$

$0 \quad 0$

$\begin{array}{llll}1 & 1.0 & 0 & 0\end{array}$

* n.i.: not investigated.

\section{Histological examination}

Changes in the epiphyseal plates and metaphyses

Evidence of rickets or of generalized osteodystrophia fibrosa was not demonstrated on histological examination of sections from the costochondral junctions of ribs in materials I, II, III and IV. The pericytic osteolysis and the osteoclasia seemed in general not to be of a pathological nature, though there were marked local changes in connection with lesions in the distal epiphyseal plate of the ulna. Local, small irregularities in the epiphyseal plates were common, most often as eosinophilic streaking along the cartilage columns, but also as irregularities in length and direction of the cartilage columns, without vessel ingrowth into the columnar cartilage, or the bone tissue, being affected. The most marked changes occurred in the distal epiphyseal plate of the ulna, where randomly directed cartilage columns, splits in the epiphyseal plate, cartilage islets, necrotic cartilage, haemorrhages and fibrous masses in the metaphysis and partly resorbed bone spicules were common histological findings. The vessel ingrowth from the metaphysis into the colum- 
nar cartilage was hindered in smaller or larger areas. Otherwise the picture varied with the degree of the lesion and the stage to which repair had progressed. Histological examination of the local projections penetrating the distal epiphyseal plate of the femur showed these to be well defined, consisting of bony and fibrous tissue most often arranged longitudinally towards the surface of the projections, partly covered with cartilage at the base (Fig. 13). The projections in the epiphyseal plates of the head of the femur and head of the humerus had a more irregular

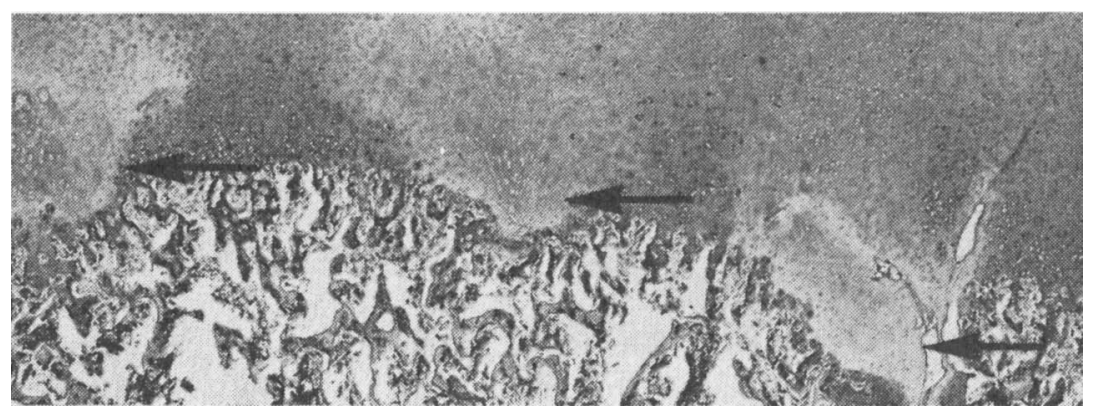

F i g u r e 14. Section from the medial condyle of the femur of a $30 \mathrm{~kg}$ pig with thickened, pale deep layer joint cartilage (arrows). (H.E.) $\times 15$. Diagnosis: Osteochondrosis.

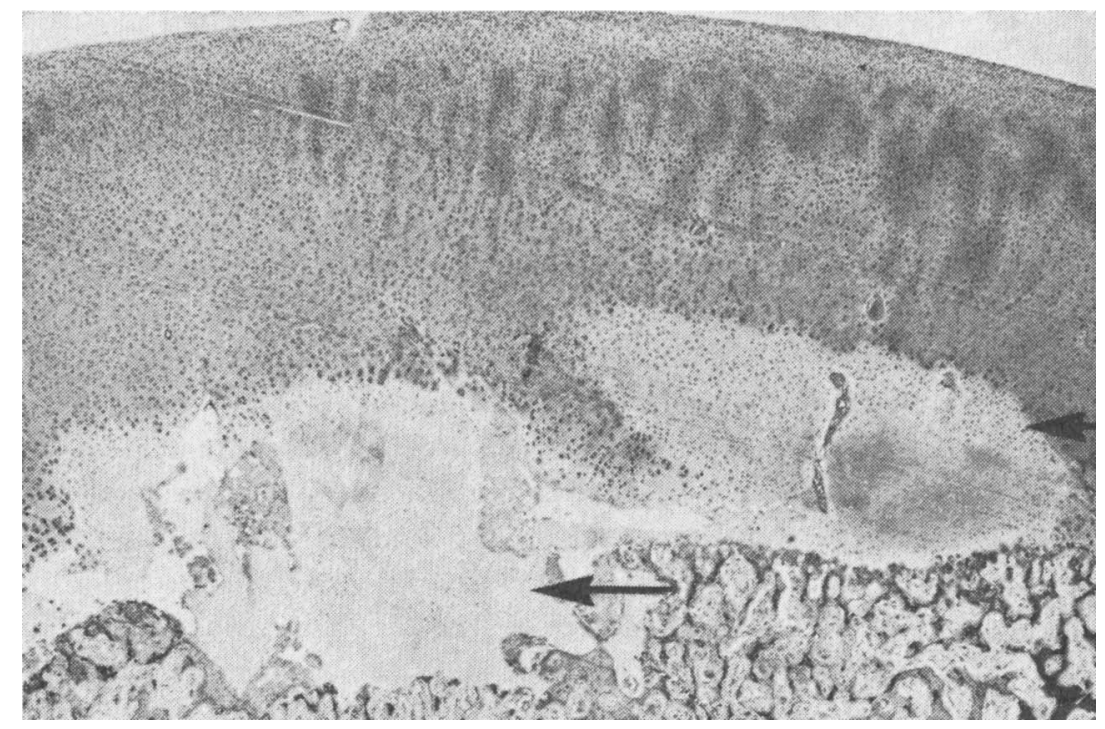

F i g u re 15. The same as Fig. 14 of a $40 \mathrm{~kg}$ pig. (H.E.) $\times 15$. 
structure with the occasional occurrence of necrotic masses at the junction to the metaphysis, and thereby an obvious hindered vessel ingrowth into the columnar cartilage.

Changes in the joint cartilage and subchondral bone tissue

As was the case with the epiphyseal plates, there were also eosinophilic streakes along the cartilage columns in the joint cartilage, the bone spicules being most often unaffected. Where separation of cartilage of normal thickness along the osteochondral junction had taken place, a varying amount of fibrous tissue was usually demonstrated along and in the crack (Fig. 2). Where there were distinct folds in the cartilage as demonstrated in the joint surface of the scapula, there could be small amounts of fibrous tissue subchondrally and between the bone spicules, and usually a discontinuity between cartilage tissue and the subchondral bone tissue.

Because of the high incidence of patho-anatomical changes in the medial condyle of the femur, this was systematically investigated in the animals comprising material IV. Local changes in the depth of the joint cartilage, which consisted of small areas of pale cartilage, were demonstrated in animals down to $18 \mathrm{~kg}$ live weight. The cartilage often penetrated into the underlying bone tissue. It was poor in cells, homogeneous, and without a columnar structure, occasionally almost necrotic, and had a more or less distinct junction with the overlying cartilage. The overlying cartilage had of ten formed so-called "brood capsules" in a line towards the underlying cartilage (Figs. 14, 15, 16, 17, and 18). The pathologically changed cartilage could have a fairly distinct junction with the bone spicules, which then appeared normal. More often, especially in animals more than $70-80 \mathrm{~kg}$ live weight, and to varying degrees, the presence of connective tissue, haemorrhages, necroses, cartilage islets, and resorption and microfractures of the bone spicules was demonstrated. In severe cases, the overlying cartilage could be folded, cracked, or partly or completely separated (Figs. 5 and 6). The initial changes in the joint cartilage appeared to be in principle the same in young and older animals. However, the incidence was higher in the older animals (Table 8), in which the changes in the bone tissue and superficial joint cartilage were also of a more severe degree. 


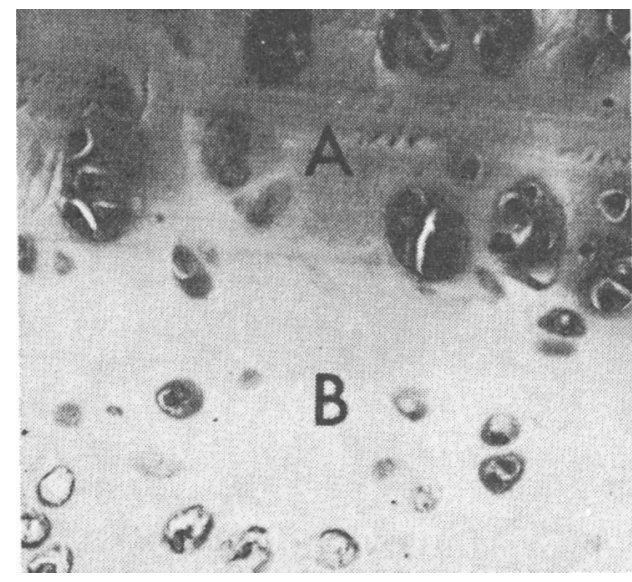

F i g u re 16 . Detail from Fig. 15. A: Joint cartilage with "brood capsules" of cartilage cells. B: Pale cartilage with few cartilage cells. (H.E.) $\times 250$.

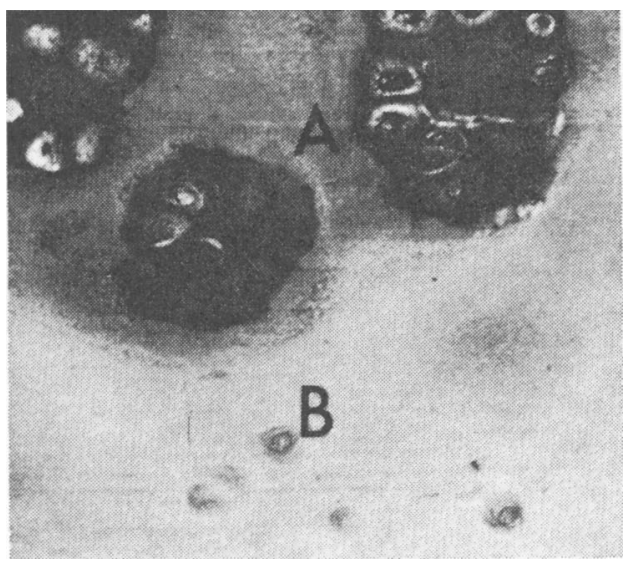

F i g u r e 17 . Detail from thickened cartilage of the medial condyle of the femur from a $70 \mathrm{~kg}$ pig. A: Joint cartilage with "brood capsules" of cartilage cells. B: Amorphous masses of pale cartilage with very few cartilage cells.

(H.E.) $\times 250$.

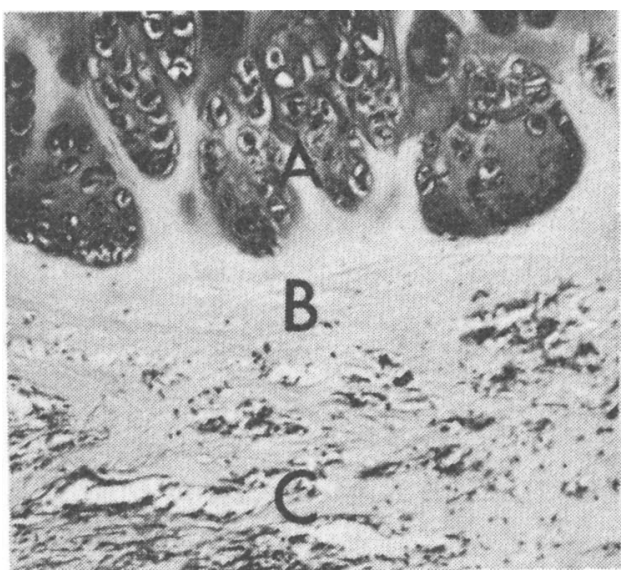

Fig u r e 18 . Detail from thickened cartilage of the medial condyle of the femur from a $100 \mathrm{~kg}$ pig. A: Joint cartilage with "brood capsules" of cartilage cells. B: Amorphous masses of pale cartilage. C: Fibrous tissue replacement. (H.E.) $\times 250$. 
T a b l e 8. The incidence of osteochondrosis in the medial condyle of the femur, histologically examined in material IV.

\begin{tabular}{lccc}
\hline $\begin{array}{l}\text { Live weight } \\
\text { of the pig }\end{array}$ & $\begin{array}{c}\text { Number of pigs } \\
\text { investigated }\end{array}$ & \multicolumn{2}{c}{ Osteochondrosis } \\
\cline { 3 - 4 } & number & $\%$ \\
\hline $10-20 \mathrm{~kg}$ & 20 & 2 & 10.0 \\
$20-30 "$ & 10 & 2 & 20.0 \\
$30-50 "$ & 13 & 6 & 46.2 \\
$50-80 "$ & 18 & 14 & 77.8 \\
\hline
\end{tabular}

\section{Bacteriological examination}

This was carried out on the joint capsules of 10 animals exhibiting the described joint capsule changes together with arthrosis, and on 5 of the markedly degenerated nuclei pulposi. No bacteria were demonstrated.

\section{DISCUSSION AND CONCLUSIONS}

The present investigation shows that the joint and bone lesions which have been described during the last 20 years in growing pigs (among others, Christensen 1953, Sabec et al. 1961, Thurley 1965, 1969, Walker et al. 1966, Hansen \& Reiland 1968, Nordrum 1968, Ljunggren \& Reiland 1970, Nielsen 1973) also occur very commonly in Norwegian pigs. Although somewhat varying groupings of the lesions are employed, the descriptions and figures suggest that the lesions are in principle the same in the various countries.

In the medial condyle of femur also pigs below $50 \mathrm{~kg}$ live weight show a high incidence of osteochondrosis (Table 8). It must be assumed that this causes the subsequent arthrosis which develops at the same site. The first step in the development of arthrosis in the stifle joint is thus present at a very early stage. It is probable that this is not just so in the case of the stifle joint, but also to a certain degree true in general. Most of the pigs at $100 \mathrm{~kg}$ live weight had 1 lesion or other in 1 joint or other. Lesions occurred in sows, boars as well as castrates. They were usually symmetrical, and incidence and degree were most marked on the medial aspect of the larger joints - that is the medial condyle of the femur and the medial condyle of the humerus, as well as the distal epiphyseal plate of the ulna. Severe lesions in the distal joints of the extremities were uncommon. On the other 
hand, arthrosis in the intervertebral joints in the lumbar region was often demonstrated. Hansen \& Reiland also demonstrated changes in the intervertebral joints. Otherwise these joints are not specifically mentioned in papers describing skeletal lesions in young pigs. The other lesions demonstrated seemed to be localized at the same sites in joints and bones, and to occur at about the same level of incidence as described in the literature mentioned above. Thus Norwegian pigs, in addition to the lesions reported from other countries, have marked changes in the lumbar intervertebral joints.

Most of the authors referred to have applied the diagnosis arthrosis or deforming arthrosis to the changes. In man (Smillie 1960 ) and dog (Craig \& Riser 1965, Birkeland 1967) the diagnosis osteochondritis or osteochondrosis dissecans is applied to the changes which are similar to those most commonly demonstrated in the pig. Jubb \& Kennedy (1970) employ this diagnosis also with regard to the commonly demonstrated joint changes in the pig. Ljunggren \& Reiland and Grondalen (1972) have employed the diagnosis osteochondrosis with regard to the local, apparently primary degenerative changes in the joint cartilage and bone tissue. The lesions demonstrated in the distal epiphyseal plate of the ulna seem to be the same as those described by Walker et al. (1966) in England, and which Thurley (1969) calls endochondral osseous dysplasia. A common characteristic possessed by all the lesions described in the present paper as osteochondrosis, and by the lesion described by Thurley (1969) as endochondral osseous dysplasia is a local, primary non-inflammatory abnormality in endochondral ossification. This criterion was also used by $L$ junggren \& Reiland for the diagnosis of osteochondrosis. It is considered proper that the diagnosis osteochondrosis covers all such abnormalities of a local nature in the joint cartilage as well as epiphyseal plates. This will simplify the systematics and nomenclature. It is a morphological diagnosis applied to a condition which can be due to varying aetiological factors, acting systemic or local. The pathogenesis does not seem to be clear. Histological investigations of the medial condyle of femur suggest that the primary changes occur in the deep layer of the cartilage, and that the changes in the bone tissue and the superficial layer of the cartilage are secondary. Osteochondrosis seems to be the same condition as called osteochondritis in man and dogs. Osteochondritis gives rise to osteochondritis dissecans. Oste- 
ochondritis dissecans gives rise to osteoarthrosis (Olsson 1971). In an attempt to simplify the nomenclature the diagnosis arthrosis without any prefix is applied when primarily degenerative or proliferative lesions affect the superficial and the deep layers of the joint cartilage. The terms osteoarthrosis and deforming arthrosis could also be used (Olsson 1971). However, these diagnoses and the diagnosis osteochondrosis dissecans will not be used, as these conditions according to the mentioned criterions, are covered by the diagnosis arthrosis.

The distinct cone-shaped projections in the distal epiphyseal plate of the femur have been desoribed previously by Zimmermann (1959-60) who supposed that they functioned to reinforce the epiphyseal plate. They are not referred to by the other authors mentioned. The rounded projections of epiphyseal plates might weaken the plate and be a predisposing factor in epiphyseal separation, or lead to premature closure of the plate.

Arthrosis and other pathological conditions in the intervertebral joints occurred in $35 \%$ of the pigs in material II, of which $12 \%$ were of a severe degree. This is a high incidence, especially when seen on the background that it is probably a progressive condition and that the pigs were on average only about $61 / 2$ months old when slaughtered. Degenerated intervertebral discs were also common in material II. Bacteriological investigation of these was negative. However, Grabell et al. (1962) have demonstrated that swine erysipelas bacteriae often give changes in the intervertebral discs of pigs, and Spiegel et al. (1972) were of the opinion that infection was the cause of changes in the intervertebral discs of children.

Arthrotic changes in the hock joint, which among others Sabec et al. (1961) have described, also occur in Norway. Compared with the other joint changes demonstrated, it nevertheless seems that tarsal changes are of little significance in growing Norwegian pigs.

Reactions in the form of haemorrhages and oedema in the capsules and ligaments were common findings. It is, however, difficult to interpret these findings because of the hard strain to which pigs are subjected before slaughter. What they do show for certain is that the ligamental apparatus of young pigs is easity overstresised.

On comparison it will be seen that there was a markedly greater incidence of bone and joint lesions in materials $I$ and 
II than in the others. Material I comprised partially selected boars, somewhat heavier than pigs in the other materials, and thus a relatively high incidence of lesions among these might be expected. As regards material II, there seems to be no immediately obvious explanation for the high incidence of osteochondrosis and arthrosis, where a $16 \%$ incidence of arthrosis in the medial condyle of the femur is markedly higher than for the remaining slaughter pigs (5.2\% in material VI). The herd was not fer at an especially high level, and the $\mathrm{Ca}$ and $\mathrm{P}$ content of the ration was greater than was the case for material III. Nielsen and Grondalen have moreover demonstrated a greater difference in the incidence of joint lesions between litters than between groups in feeding trials with $\mathrm{Ca}$ and $\mathrm{P}$ as variable trial factors. One therefore ought to think more of heredity rather than feeding as the reason for the unusually high incidence of joint lesions in this material.

Lesions similar to those described by Thurley (1969) were found on histological examination of the epiphyseal plates and joint cartilage. It is felt, like Thurley (1969) did, that they must be considered as pathological findings. All the gross changes demonstrated in the joint cartilage must also be considered pathological when seen in the light of what is at the present time considered to be normal. This results in the situation that all growing pigs today have pathological lesions to a greater or lesser extent in the skeleton. It is therefore important to clarify which types of lesion, and which parts of the skeleton that trouble the animal, especially with regard to its ability to move.

\section{ACKNOWLEDGEMENTS}

Thanks are due to the Norwegian Pig Breeders Association and to the Department of Animal Husbandry and Genetics, Veterinary College of Norway, for help in obtaining material, to the Department of Microbiology and Immunology, Veterinary College of Norway, for carrying out the bacteriological investigations and to the Photographic Laboratory, Veterinary College of Norway, for taking the photographs.

\section{REFERENCES}

Birkeland, R.: Osteochondritis dissecans in the humeral head of the dog. Nond. Vet.-Med. 1967, 19, $294 \longrightarrow 306$.

Bollwahn, W., E. Lauprecht, J. Pohlenz, W. Schultze \& E. Werhahn: Untersuchungen über das Auftreten und die Entwicklung der Arthrosis deformans tarsi beim Schwein in Abhängigkeit vom 
Alter der Tiere. (Investigations on the incidence and the pathogenesis of arthrosis deformans tarsi in swine in relation to the age of the animal). Z. Tierzüchtg Züchtgsbiol. 1970, 87, 207219.

Christensen, N. O.: Impotentia coeundi in boars due to arthrosis deformans. Proc. XV Int. Vet. Congr., Stockholm 1953. Part I, 2, $742-7.45$.

Craig, P. H. \&W. H. Riser: Osteochondritis dissecans in the proximal humerus of the dog. J. Amer. vet. Rad. Soc. 1965, 6, 40-49.

Garm, O.: Lecture, Oppland Vet. Soc. 1968. (Unpublished).

Grabell, I., H.-J. Hansen, S.-E. Olsson, K. Orstadius \& E. Thal: Discospondylitis and arthritis in swine erysipelas. Acta vet. scand. $1962,3,33-50$.

Grøndalen, T.: Anatomical construction of the elbow and the knee joints in relation to joint lesions in young pigs. Proc. 2. I.P.V.S. Congr., Hannover 1972, 67.

Hansen, H. J. \& S. Reiland: Ledlidanden hos avelssvin. (Joint lesions in breeding pigs). Lact. Symp. Wenner-Gren Center, Stockh. 1968, 105-111.

Jubb, K. V. F. \& P. C. Kennedy: Pathology of domestic animals. 2nd Ed., Acad. Press 1970, 1, 77.

Lauprecht, E., W. Schulze \& W. Bollwahn: Untersuchungen über das Vorkommen von Bewegungsstörungen und Erkrankungen der Gliedmassen bei Fleischschweinen. (Investigations on locomotor disturbances and joint lesions in pigs). Z. Tierzüchtg Züchtgsbiol. 1967, 83, 297-311.

Ljunggren, G. \& S. Reiland: Osteochondrosis in adolescent animals: An endocrine disorder? Calc. Tiss. Res. 1970, 4, 150-151.

Nielsen, N. C.: Arthrose hos svin. (Arthrosis in pigs). Nord. Vet.-Med. $1973,25,17-27$.

Nordrum, E.: Rakittlignende tilstander hos slaktegris. (Rickets-like conditions in bacon-pigs). Medlemsbl. norske Vet.-Foren. 1968, $20,389-392$.

Olsson, S.-E.: Degenerative joint disease (osteoarthrosis): A review with special reference to the dog. J. small Anim. Pract. 1971, $12,333-342$.

Sabec, D., E. Schilling \& L. Cl. Schultz: Eine Arthrosis deformans des Sprunggelenkes beim Schwein. (Arthrosis deformans of the hock joint in pigs). Dtsch. tierärztl. Wschr. 1961, 68, 231-236.

Smillie, I. S.: Osteochondritis dissecans. E. \& S. Livingstone Ltd., Edinburgh and London 1960.

Spiegel, P. G., K. W. Kengla, A. S. Isaacson \& J. C. Wilson: Intervertebral disc-space inflammation in children. J. Bone Jt Surg. 1972, $54 \mathrm{~A}, 284-296$.

Thurley, D. C.: Arthropathy in pigs. Proc. Roy. Soc. Med. 1965, 58, $369-370$.

Thurley, D. C.: Changes in the epiphyseal cartilage of immature pigs without clinical lameness. Path. vet. 1969, 6, 217-226.

Vaughan, L. C.: Leg weakness in pigs. Vet. Rec. 1971, 89, 81-85. 
Walker, T., B. F. Fell, A. S. Jones, R. Boyne \& M. Elliott: Observations on leg weakness in pigs. Vet. Rec. 1966, 79, 472-479.

Zimmermann, $W .:$ Untersuchungen am Femur des Hausschweines. (Investigations on the femur of pigs). Z. wissensch. Zool. 1959$60,162,96-127$.

\section{SAMMENDRAG}

Osteochondrose og arthrose hos gris.

I. Forekomst hos dyr opp til $120 \mathrm{~kg}$ levende vekt.

Ledd- og skjelettlesjoner hos voksende griser er beskrevet etter post mortem unders $\varnothing$ kelse av 341 purker, råner og kastrater fra 10 til $120 \mathrm{~kg}$ levende vekt, og 869 enkeltknokler fra griser mellom $80 \mathrm{og}$ $11.5 \mathrm{~kg}$ levende vekt ved slakting. Det ble ikke påvist rakitt eller osteodystrofia fibrosa generalisata. Lesjonene opptrådte hos begge kjønn. De typiske osteochondrale lesjonene var oftest symmetriske, opptrådte på bestemte steder i ledd og epifyseplater og var mest uttalt i albu- og bakkneledd, og $\mathrm{i}$ den distale epifyseplate av ulna. Lesjoner av forskjellig grad ble påvist hos de fleste griser ved $90-100 \mathrm{~kg}$ levende vekt. En foreslår å bruke diagnosen osteochondrose om lokale, primært ikke-infeksiøse forstyrrelser som fører til svikt i den endochondrale forbeining, både i leddbrusk og epifyseplater. Diagnosen arthrose er brukt når den overflatiske del av leddbrusken er affisert. Undersøkelser av forandringer på et tidlig stadium i den mediale condyl av femur, tyder på at de osteochondrale lesjonene starter $i$ det dype lag av leddbrusken. Arthrose forekom ofte $i$ intervertebralledda i lumbaldelen av ryggen hos norske griser. Ellers synes lesjonene a være identiske med de som er beskrevet fra andre land.

(Received September 13, 1973).

Reprints may be requested from: Trygve Grøndalen, Veterinary College of Norway, Postboks 8146, Oslo Dep., Oslo 1, Norway. 